$\triangle$ CTA NEOPHILOLOGICA

UDK: 821.111(73).09-31Cisneros S.

DOI: 10.4312/an.51.1-2.25-38

\title{
Shortcomings and Limitations of Identity Politics and Intersectionality in Sandra Cisneros's The House on Mango Street
}

\section{Lilijana Burcar}

\begin{abstract}
The article offers a systematic critique of identity politics and intersectionality that today dominate Western mainstream literary theory and Anglo-Saxon literary production by bringing to the fore a much overlooked critical intervention on the part of materialist (literary) system theorists and Western Marxist feminists. It then dissects the ways in which the trappings of identity politics and its upgraded version of intersectionality are manifested in Sandra Cisneros's The House on Mango Street, with the class in the triad of class, race and gender eventually weakened and removed from view.
\end{abstract}

Key words: class, race, gender, identity politics, intersectionality, The House on Mango Street, Sandra Cisneros 


\section{INTRODUCTION}

The House on Mango Street (1984) is a contemporary American classic, written in the form of vignettes and told from the point of view of a first-generation Mexican-American girl, who lives in a Chicago ghetto. The narrator recounts the trajectory of her growth from early childhood to adolescence and beyond by placing it within what mainstream critics acknowledge to be "the socio-political frame of poverty, racial discrimination and gender subjugation" (Olivares 209). But what appears to be a coming-of-age novel whose protest, according to mainstream critics, seems to be channelled into undoing and overcoming the constructs of race, class and gender in fact gives way to a form of bildungsroman concerned primarily with a seemingly isolated issue of gender. Race and class, as this article argues, in fact resurface sporadically, forming a background tapestry to the discussion of women's oppression and gender subjugation. Moreover, with systemic exploitation and racism not only disconnected from gender but pushed into the background as seemingly separate and decontextualized phenomena, Cisneros's attempt at coming up with a progressive bildungsroman encounters major difficulties and ideological traps. These stem from the novel's subscription to essentialist identity politics and to its upgraded but equally problematic version of intersectionality, which has dominated contemporary American literary production and Western academia since the early 1980s.

Systemic analysis and materialist literary approach (Eagleton), unlike identity politics and its upgraded intersectionalist variant, rest on the understanding of gender and race as integral building blocks of capitalist exploitative relations. Racism and patriarchy are seen as inherent to the functioning of capitalism, constituting its operating subsets rather than being separate and decontextualized categories that according to identity politics exist outside the socio-economic system, or, according to intersectionalists, merely run parallel to it as ahistorical phenomena. System theoreticians headed by Marxist feminists argue further that these categories are neither mutually exclusive, a view disseminated by proponents of identity politics, nor are they only intersectional and thereby tangentially overlapping, which is a modified approach promoted by intersectionalists. System/Marxist feminists instead see these categories as structurally "co-synthetic" (Volpp 1202) and historically specific. Proponents of identity politics, on the other hand, view gendered and racialized categories as self-generating phenomena existing outside broader social relations, thus dismissing the structural causes of their emergence and maintenance. As a result, racism and gender subjugation are reductively interpreted as a matter of individual prejudices, and as driven and sustained simply by negative attitudes that men as a group supposedly uniformly foster towards women and whites against those defined as racialized others. Or, 
as put by Sleeter, identity politics "locates sexism [and racism] in biased attitudes of individuals who [supposedly automatically and wholesomely] limit the opportunities of other individuals by [simply] treating them stereotypically" (84). Accordingly, patriarchy is conceptualized as prehistoric and universal, and women's secondary status and gender oppression the result of oppressive attitudes and prejudices supposedly deeply and universally seated in individual men. Similarly, racism is conceptualized as an atavistic leftover of supposedly no longer existing institutional practices. It is presented as a matter of individual bad taste and moral corruption, with social exclusions not structurally but individually conditioned, that is, as arising from a handful of prejudiced individuals targeting other individuals (Wilson 1996). In this way, as pointed out by Choonara and Prasad: "the enemy of the black [remains] white and the enemy of the woman is man. And all whites are racist like all men are sexist" (N. pag.).

\section{LIMITATIONS OF IDENTITY POLITICS AND INTERSECTIONALITY}

The othering of women, which rests on their definition as universally feminine, has been fundamental to capitalist exploitative relations (Lister 1997). Identity politics, which insists on women's marginalization and gender subjugation being a matter of prejudices and negative behaviour of individual men towards women, avoids these historic conditions and structural demands that have given rise to the contemporary form of institutional patriarchy in Western liberal democracies (Moi 1986). The othering of women has served as a device to justify a new division of labour essential to industrial capitalism which was consolidated in the $19^{\text {th }}$ century, and which has ever since rested on the privatization rather than socialization of social reproduction such as child care and elderly care (Burcar Restavracija). In its appropriation of wealth, capital is structurally dependent on women's different degrees of domestication and the institutional maintenance of their secondary and (semi-) dependent status, or, as put by Mies, on (different degrees of ) their "housewifization" (ix). This also leads to the imposition and structural enforcement of women's secondary status as workers, who are paid for the same work much less than men. Industrial capitalism ushered in a new form of institutional patriarchy based upon the nuclear family and breadwinner model, which in Western capitalist democracies today continues to hold sway in the form of the so-called 1.5 breadwinner model with women, due to the lack of institutionalized child and elderly-care, employed only part-time and for this reason still dependent for their pension and health social transfers on the employment status of their partners/husbands (Burcar Restavracija). Rather than patriarchy being 
prehistoric and women's gender subjugation a matter of prejudice, its form and content is historically specific and most certainly not universal to all societies as it is bound up with specific socio-economic arrangements.

Accordingly, identity politics also dismisses the structural causes of institutional racism and the reasons for its ongoing perpetuation. Rather than being a matter of individual bias and prejudice, racism is structurally conditioned and systemically maintained. Its origin lies not in "exogenously determined attitudes" (Reich 3), but in "historical, economic and political factors" (Cole 14), associated with the rise and consolidation of capitalist exploitative system in the West and its imperialist expansionism. From its inception, capitalism in the West has been a "racist project" (Brown and de Lissovoy 608) and race as a social construct was invented and maintained (also by means of pseudoscience) to be deployed "strategically" (Smith 188). Racialization has proceeded on the basis of projecting imaginary insufficiencies and negative characteristics into people under the pretext of their skin colour and has served as a way of dehumanizing and objectifying them. Only by being stripped of their personhood, could the racialized others be turned into a pool of disposable working bodies, bodies worth less than others, and put into the service of fledgling capitalist class as another natural resource that needed to be paid nothing or next to nothing. Racialization in all its forms and stages of capitalism has been "a tool to exploit labour more thoroughly" (Bonacich et. al. 352). It has "historically functioned to legitimize extreme oppression and inequality" (Wilson 125), that is, super-exploitation of those constructed and denigrated as racialized others on the home turf of Western imperial capitalist states as well as in their colonial outposts. Racism in the capitalist democracies of the late $20^{\text {th }}$ and early $21^{\text {st }}$ centuries continues unabated: its form and content have gone from biological racism to cultural racism, with these "newer colour-coded forms of racism [...] directed at migrant communities", which today constitute one of the basic supplies of institutionally cheapened and super-exploited labour for capital (Cole 25).

Intersectionality, which functions as a sophisticated extension of identity politics, fails to acknowledge that Western capitalist democracies have been and continue to be based on a racial contract (Brown and de Lissovoy 600) and a sexual contract (Pateman 1988). It avoids the issue of gender and racial oppression being structurally integral to capital accumulation and the fact that these undergo modifications in content and form but will not be done away with as long as this set of relations exists. Intersectionality - also referred to as the theory of race, gender and class - takes these categories as givens, just like identity politics whose tenets it replicates, but attempts to complicate them by claiming that these categories can at certain moments combine or interlock/intersect, thus affecting such individuals differently. In this way, one can experience 
different or multiple oppressions, which are seen to emanate from people's prejudices and negative attitudes, and one can at one point occupy the position of an oppressor and at another that of the oppressed or both at the same time. The result is an endless multiplication of categorical permutations so that, as exemplified by Mitchell (2 December 2013, N. pag.), "a ruling class, gay, black man will have a different experience, and therefore, a different politics, than [for example/say] a straight, white, working class woman". Intersectionality has been rightly critiqued as being "limited, [merely] descriptive and non-explanatory" (Gimenez 28), and despite its appearance to the contrary as still essentialist and divisive. All it enables us to do, according to its critics, is to merely "map the distribution of the population in these manifold locations" and "to investigate the extent to which identities coincide or not" but it "cannot explain either the source of inequalities or their reproduction over time" (Gimenez 28-29).

This is also directly related to the fact that intersectionality treats race, gender and class as equivalents. In this way, it redefines class as another form of oppression, functioning supposedly in isolation from and at times in combination with, and therefore, crucially, always on the same level as race and gender. But as pointed out by Gimenez, "class is qualitatively different from gender and race" (30): while gender and race are social constructs and ideologies, class "is not simply another ideology legitimating oppression; rather it denotes exploitative relations between people mediated by their relations to the means of production" (24). In this way, intersectionality removes from view the understanding of class as "the crucial social relation on which depends the ability [..] of capitalism to sustain and reproduce itself" (Cole 23). In other words, class represents the basic and fundamental determinants of the organization of the social fabric under capitalism, to which race and gender are subsets. Intersectionality, on the contrary, flattens and thus redefines class as one with gender and race, that is, as merely another in a series of oppressions stemming from individuals who discriminate against poor people. Poverty is no longer understood to be structural and systemic but a matter of individual occurrence and negative discriminatory attitudes that bar people from access to education and housing, thus causing or entrenching their poverty. Intersectionality, according to system theorists, functions on the same level as identity politics: it simply recreates "a list of naturalized identities, abstracted from their material and historical context" (Mitchell N. pag.), and more than that, it depoliticises class by turning it into its opposite, a non-relational identity category. The end result is again "the perpetual articulation of difference" whose structural origins remain obscured and consequently unaddressed, which has led to "the fragmentation and stagnation of political activity" (Cole 23). The focus is instead on discriminatory attitudes as though these were the sole originator and the driving force of what are in fact structural 
and systemic inequalities. In this way, exploitative social relations, which are the crux of structural inequalities, remain unaddressed. This is also an essential problem that plagues The House on Mango Street.

\section{CLASS, RACE AND GENDER TRIANGLE IN THE HOUSE ON MANGO STREET}

Cisneros also subscribes to the view that identity is a composite of separate and at best only tangentially overlapping categories. In the novel, class or structural relations of systemic exploitation is flattened to the same level as ideologies of race and gender in order to be, prototypically, remoulded into its opposite, that is, the weakest link in the triad of race, gender and class. As a result, a major class issue such as poverty, for example, seems to be self-generating and self-originating rather than structurally induced and reinforced. Poverty seems to cling to the Chicana/o community as an inexplicable curse that for some mysterious reason cannot be left behind. This is best seen in the description of the housing conditions the narrator's family like the rest of her community has to endure, and in the family's search for a house of their own which yields unsatisfactory results.

The house is an essential symbol in The House on Mango Street. First, what Esperanza, the narrator, reminds us is that her family "didn't always live on Mango Street" and that what she "remember[s] most is moving a lot" (Cisneros 3). Frequent relocations speak of frequent evictions and dislodgings. Esperanza's parents are the so-called working poor, with her Mexican father scraping a living as a private gardener in a house whose inhabitants "sleep close to the stars" while every day he "wakes up tired in the dark, drinks his coffee and is gone before his children wake" (57). With little or below-poverty income, the family is left to its own devices and forced to rent whatever inadequate and cramped lodgings there are momentarily available on the market, which also leaves the family at the mercy of their landlords. This and the inadequacy of housing conditions is driven home in what is one of the most explicit descriptions provided by the narrator who remembers that once they "had to leave the flat" they rented "quick": "The water pipes broke and the landlord wouldn't fix them because the house was too old." (4).

The narrative hints at the discrepancy between the myth of American dream and the reality that Mexican and other Latin American immigrants have had to face for generations as a result of being subjected to systemic exploitation. The novel, however, never alludes to these conditions directly with the house serving only as an implicit symbol of poverty. The narrative contrasts the romanticized image of the home found in official media and other propaganda apparatuses 
against the grim reality faced by the super-exploited Chicana community. It does so by dwelling on the narrator's resentment against her parents and their promises:

[Mama and Papa] always told us that one day we would move into a house, a real house that would $[\ldots]$ have real stairs, not hallways stairs, but stairs inside like the houses on TV. ... The house on Mango Street is ours [...] But even so, it's not the house we thought we'd get" (3).

After years of drudgery and hard work, Esperanza's parents have to do with a house that still shows all the signs of poverty and according to the girl narrator "isn't it" (5). The house is "small and red with tight steps in front and windows so small you'd think they were holding their breath. Bricks are crumbling in places, and the front door is so swollen you have to push hard to get in." (4). The "tightness, suffocation, and decay" of the house on Mango Street are reflective of Esperanza's and the rest of the community's exploitation, which, according to Martin, translates into "a nailed, barred, prison-like space" (56). But why the family is stuck in a vicious circle of poverty and has to make do with only modest improvements to their secondary status despite all the hard work, however, remains a mystery. Poverty is not problematized as constructs of gender are in this novel. Instead, it is merely alluded to in descriptive and static terms and presented as yet another among many of the unrelated phenomena that plague the narrator in her childhood and late teenage-hood. In this way, it only constitutes a backdrop to what appears to be a separate and more troubling issue of gender oppression.

Moreover, when poverty is treated directly, it is presented as a given state of affairs. The causes of structural poverty and its negative impact on the overall well-being of those directly affected by it are removed from view. The issue of poverty is instead evoked and repackaged as a matter of negative, even hostile, treatment Esperanza experiences as a child whose family is poor. This is evident from the following exchange:

"Once when we lived on Loomis, a nun from my school passed by [...] Where do you live? she asked. There, I said pointing up to the third floor [...] the paint peeling. You live there? The way she said it made me feel like nothing." (4-5).

The issue of poverty is reduced to a matter of insulting behaviour and discriminatory attitudes individuals harbour against those they perceive as less fortunate than themselves, and to a matter of personal responsibility and internalized blame on the part of its victims. In this way, it is those at the receiving end who end up being blamed for finding themselves in a trap not of their own making, a stance which the narrative does not counter. Structural poverty thus comes across and is implicitly invoked as people's own responsibility and personal fault. 
In this respect, Cisneros's novel stands apart from other Chicana novels of maturation (e.g. by Helena Viramontes, Anna Castillo, Cherrié Moraga and Isabella Rios) that contextualize the plight of immigrants within a broader geopolitical capitalist system of socio-economic relations of exploitation. They point to the direct involvement of American corporations and the IMF in the dispossession and displacement of Latin Americans, which forces them to emigrate. Unlike Cisneros's, these narratives inadvertently foreground the forces behind "the creation of a Mexican transnational labour force in the US" and "the local repercussions" that follow (Oliver-Rotger 305) to keep it controllable and pliable. They point to legally sanctioned and systemic exploitation of Mexican immigrant workers through the government's imposition of a permanently temporary and therefore non-citizen status on the majority of racially marked immigrant workers (Sharma). This has resulted in the consolidation of appalling working and living conditions for agricultural, industrial and service-based Latin American immigrant workers, below-poverty payments and "harsh laws against the legal and illegal immigrants' rights to the welfare services" (Oliver-Rotger 305). All of this translates into the shaping of a specific social position or structural location members of Chicano communities find themselves locked into, and which also explains the real causes of their structurally induced poverty.

Systemic exploitation is structurally intertwined with the racialization of the Chicana community, which in the novel translates into "a sense of otherness, exclusion, objectification" and powerlessness on the part of its members (Martin 57). Dilapidated living conditions the novel alludes to are not exclusive to Esperanza's family. They serve as a mark of systemic poverty that is naturalized and deepened through the racialization of Latin Americans in the US. Within this frame, the exploited are systematically rendered invisible as humans and turned instead into mere disposable bodies to be made use of and cast off indiscriminately. Their social welfare is not a matter of concern. This is even more explicit in the case of Mexican newcomers, especially undocumented workers, derogatorily referred to as wetbacks, which is a racial slur for those who have once crossed the Rio Grande and ended up working as indentured labour in the Southwestern fields in boiling summer temperatures. This state of affairs is hinted at between the lines in the vignette Geraldo, No Last Name. Geraldo is an undocumented worker, who is a victim of a hit-and-run accident and bleeds to death. Nobody knows his last name. Anonymity entrenched by his legally racialized status as the ultimate other is a marker of his utter disposability. He might be the victim of a hit-and-run accident, but "what does it matter?" $\mathrm{He}$ is "just another brazer who didn't speak English. Just another wetback. You know the kind. The ones who always look ashamed." (64).

The racialization of Mexican Americans and their construction as "undeserving others" goes back to the Mexican-American war and the US annexation of 
California, Texas, Arizona, New Mexico and Nevada in 1849 (Cole). The newly self-installed Anglo-Saxon elite declared all Mexicans "a mixed, inferior race with considerable Indian and some black blood" so that "to take lands from such 'inferior barbarians"' was seen not as a crime but god's wish (Cole 108). Pressing them into jobs at sub-minimum wages was justified as an expression of generosity on the part of the incoming Anglo-Saxon moneyed elite. This racialization was also extended to groups of Mexican workers first recruited by agribusinesses, and mine and railway businesses under the two Bracero programs, with the first one implemented during WWI and the second one during WWII. The expression bracero comes from the Spanish word arm, and means "he who works with arms" (Mandeel 172). Bracero program was in effect an "indentured servitude program" (Vogel) which set into motion similar programs and government policies that continue to this day. The aim was to create a pool of surplus labour and a captive labour force for capital, legally stripped of basic rights and exempted from minimum labour protection laws, which would also put pressure on the rest of the wages. The Bracero program served as a template that "legally designated Mexicans as racial outsiders unfit for integration into American society" (Paret 513). It conferred upon them the status of permanent temporary migrant labour with no basic citizenship rights. This highly vulnerable (contract-bound) status that leaves Latin American immigrants subject to wholesale exploitation under the threat of deportation continues today in the form of guest worker programs. These are targeted at Latin Americans and carry "a racially exclusive character" (Paret 513). Labelled as illegal aliens whether they be documented or undocumented workers, Latin Americans under these programs are legally excluded "from federal wage and hour legislation" and have no right to form or join unions (Ness 445). They are legally exempted from access to "social services and programs such as unemployment insurance, social-assistance, old-age pensions, etc” (Sharma 472). This "structural and legal, institutional subordination of immigrant workers and their communities" is also reflected in "an escalation of workplace and community raids, detentions and deportations, racial profiling, police abuse, and so forth, [which in turn] feeds hate crimes against immigrants and generates increasing hostility towards Latino/a communities" (Robinson and Barrera 19). In these ways, "the state's repressive activities combine with corporate strategy" (ibid.) to keep people racially stratified and divided, and to keep an increasing segment of the workforce super-exploitative and supercontrollable (also by means of its criminalization), while, ironically, scapegoating it for the deepening crisis of the welfare system.

In spite of carrying an isolated and decontextualized reference to brazers (braceros) and Geraldo the undocumented worker, The House on Mango Street avoids this line of more accurate and in-depth investigation. Instead, in its pursuit of race, class and gender as separate categories that intertwine only occasionally and 
more often as a result of negative attitudes individuals display against others, it reverts its focus to interracial tensions. These are presented as self-originating, self-standing and as the source and cause of people's insecurity:

Those who don't know any better come into our neighbourhood scared. They think we're dangerous. They think we will attack them with shiny knives. They are stupid people who are lost and got here by mistake. But we aren't afraid. [...] All brown all around, we are safe. But watch us drive into a neighbourhood of another color and our knees go shakity-shake and our car windows get rolled up tight and our eyes look straight. Yeah. That's how it goes and goes. (28)

The main source of people's stigmatization and insecurity turns out to be interracial antagonism with the mainstream society and its state mechanisms being merely a passive bystander. It looks as though interracial antagonism or what are in fact learned attitudes of distrust that one group harbours towards the other is to blame for the racial oppression that pervades American society as such. These negative attitudes appear to exist by themselves and for themselves. In this sense, "structural oppression" is negated and reworked into a matter of personal attitudes or "differences" among individuals as though these were self-originating and self-standing. With structural oppression reduced to and reconfigured as an identity "difference", what drops out of view is the class itself. Institutional racialization of immigrant communities and the very construction and reproduction of racial difference to dehumanize and exempt those targeted from already minimal rights, and to artificially stratify the working population so as to keep it disunited and controllable, disappear from view. Instead, it is individual attitudes, which also define a member's group as homogeneously discriminatory, that are to blame for one's ghettoization and enclosure. According to this decontextualized thinking, ghettoes, ironically, turn out to be not such a bad thing. Identity politics, which insists on race and gender as given categories, is in a sense after all a politics of identity enclosures or self-imposed ghettoes.

In the novel, the image of the house comes to serve primarily as a recurring symbol of women's domestication and entrapment. The novel presents patriarchal constraints as synonymous with and exclusive to the Mexican-American community, and by extension to the rest of ethnicized communities (Burcar Ethnicizing). It manages to do so by cutting its gaze off from the significance that institutional patriarchy and constructs of gender have for the social organization and functioning of capitalist America as a whole. Predictably, women's confinement to household drudgery and fulltime childcare, which constricts them and makes them dependent on men, is portrayed as arising solely from men's harassing and negative attitudes towards women, automatically also undercutting their freedom 
and possibility of self-realization. This stance is best captured in Esperanza's most often quoted observation: "I guess the Chinese and Mexicans don't like their women strong." (Cisneros 10). The solution offered by the novel's conclusion is culturally essentialist: the main protagonist is to leave her community and join mainstream white America instead, thus supposedly also escaping negative treatment and patriarchal constraints, which the novel, in accordance with identity politics, reduces to individual antagonisms between men and women and as emanating by default from individual biological men. This notion becomes fully developed in the most important among the concluding vignettes titled A House of My Own, which is a pun on Woolf's room of one's own. The narrator dreams of a house and therefore of a space "all her own" (108) ensconced in the heart of mainstream America, where, according to the narrative, she is no longer weighed down and silenced by the determinants of a patriarchal culture which rests on the negative attitudes and stereotypical behaviour of the men in her community towards women. This is a house that the narrative presents as a safe haven just by the merit of existing outside the ghetto and hence a house that cannot be and is "[n]ot a man's house. [n]ot a daddy's" but "[a] house of my own" with "[n]obody's garbage to pick after" (108).

It is precisely at this point that identity politics finally backfires. To join mainstream America in fact does not mean escaping institutional patriarchy at all. In a country where women's secondary status is directly tied to the privatization of social reproduction, women continue to be entrapped by official policies that encourage women's domesticity in the form of a modernized breadwinner model, precisely in order for the capitalist state to avoid investing into a public network of accessible and full-day childcare facilities. Limited institutional childcare (especially for children under three years of age) leads to prolonged maternity and parental leaves for women on the one hand and part-time jobs on the other, which automatically edges women out of long-term, formal (full) employment, making them dependent on their partners. The so-called successful women can avoid this entrapment only by outsourcing domestic work and care, which is to be carried out at the expense of the well-being of other, especially poorer and most often immigrant women. Relocation to the mainstream society means acquiescing to the very same system of structurally maintained forms of women's domestication and oppression that also hamper women in the ghetto (Burcar Ethnicizing). In its isolated treatment of gender and patriarchy, Cisneros's novel also obfuscates and evades a clear structural linkage between gendering, racialization and ghettoization, which in turn structurally defines the position of migrant women within and outside what are in fact permeable rather than sealed borders of their racialized communities. In this way, it overlooks the system of racially driven "double wages", and along with it even lower gendered double wages paid to immigrant women, 
which has been a permanent feature of US employment policies (Oliver-Rotger 138). Mexican and other Latin American immigrant women who today work either in North American urban sweatshops or fields together with children to supplement the meagre, depressed wages of their husbands are facing exactly the same situation of state-sponsored institutional patriarchy and racism as did their counterparts at the end of the last century. This goes to show both the existence of synergetic linkage between seemingly disparate categories on the basis of which otherness is produced, and direct embeddedness of race and gender issues in the class structuration of the US society.

\section{CONCLUSION}

Even though the development of the protagonist in the novel is outward-oriented rather than solipsistic, the result, however, is a limited social awakening on the part of the narrator and the reader alike. The vignettes offer insights into the narrator's growing awareness of gender issues with racial subjugation and systemic poverty gradually edged out from the centre of investigation. As this paper has demonstrated, rather than race and gender being merely interlocking or intersecting, they are structurally intertwined and inbuilt categories of class with gender (and racial) oppression having broader and deeper structural roots that cannot be interpreted or reduced to the level of negative attitudes men supposedly uniformly harbour against women or whites against those defined as others. To do so is to fall into a trap of identity politics and its modernized version of intersectionality that take results for causes.

\section{BIBLIOGRAPHY}

Bonacich, Edna, Sabrina Alimahomed, and Jake B. Wilson. "The Racialization of Global Labor.” American Behavioral Scientist, vol. 52, no. 3, 2008, pp. 342-355. Brown, Anthony L. and Noah de Lissovoy. "Economies of racism: grounding education policy research in the complex dialectic of race, class, and capital." Journal of Education Policy, vol. 26, no. 5, 2011, pp. 595-619.

Burcar, Lilijana. "Ethnicizing women's domestic entrapment in Sandra Cisneros's The House on Mango Street." Fluminensia: časopis za filloška istraživanja, vol. 29, no. 2, 2017, pp. 113-137.

Burcar, Lilijana. Restavracija kapitalizma: repatriarhalizacija družbe. Sophia, 2015. Cisneros, Sandra. The House on Mango Street. Vintage Books, 1991.

Cole, Mike. Racism: A Critical Analysis. PlutoPress, 2016.

Choonara, Esme and Yuri Prasad. "What's wrong with privilege theory?" International Socialist, vol.142,2 April 2014, http://isj.org.uk/whats-wrong-with-privilege-theory/ 
Eagleton, Terry. Marxism and Literary criticism. Routledge, 2002.

Gimenez, Martha E. "Marxism, and Class, Gender, and Race: Rethinking the Trilogy.” Race, Gender E Class, vol. 8, no. 2, 2001, pp. 23-33.

Lister, Ruth. Citizenship: feminist perspectives. Macmillan Press, 1997.

Mandeel, Elizabeth W. "The Bracero Program 1942-1964." American International Journal of Contemporary Research, vol. 4, no. 1, 2014, pp. 171-184.

Martin, Karin W. "The House (of Memory) on Mango Street: Sandra Cisneros's Counter-Poetics of Space." South Atlantic Review, vol. 73, no 1, 2008, pp. 50-67.

Mies, Maria. Patriarchy and Accumulation on A World Scale: Women in the International Division of Labour. Zed Books, 1998.

Mitchell, Eve. "I am a woman and a human: A Marxist-feminist critique of intersectionality theory." The North Star, 2 December 2013, http://www.thenorthstar.info/?p=11425

Moi, Toril. Sexual/textual politics: feminist literary theory. London and New York: Methuen, 1986.

Ness, Immanuel. Forging a Migration Policy for Capital: Labor Shortages and Guest Workers, New Political Science, vol. 29, no. 4, 2007, pp. 429-452.

Olivares, Julian. "Entering The House on Mango Street (Sandra Cisneros)." Teaching American Ethnic Literatures: Nineteen Essays, edited by John R. Maitino and David R. Peck, University of New Mexico Press, 1996, pp. 209-235.

Oliver-Rotger, Maria Antonia. Battlegrounds And Crossroads: Social And Imaginary Space In Writings By Chicanas. Rodopi, 2003.

Paret, Marcel. "Legality and exploitation: Immigration enforcement and the US migrant labor system." Latino Studies, vol. 12, no. 4, 2014, pp. 503-526.

Pateman, Carole. The Sexual Contract. Blackwell, 1988.

Reich, Michael. "The Economics of Racism.” http://tomweston.net/ReichRacism.pdf

Robinson, William and Mario Barrera. "Global Capitalism and twenty-first century fascism: a US case study." Race E Class, vol. 53, no. 3, 2012, pp. 4-29.

Sharma, Nandita. "On Being Not Canadian: The Social Organization of 'MigrantWorkers' in Canada." Canadian Review of Sociology and Anthropology, vol. 38, no. 4, 2001, pp. 415-439.

Sleeter, Christine E. Multicultural Education as Social Activism. SUNY Press, 1996.

Smith, Vicki. David R. Roediger and Elizabeth D. Esch. "The Production of Difference: Race and the Management of Labor in the U.S. History. New York: Oxford University Press, 2012.” Administrative Science Quarterly, vol. 59, no.1, 2014, pp. 187-189.

Vogel, Richard D. "Transient Servitude: The U.S. Guest Worker Program for Exploiting Mexican and Central American Workers." Monthly Review, vol. 58, no. 8, 2017, 1-23. 
Volpp, Letti. “Feminism versus multiculturalism.” Columbia Law Revierw, vol. 101, no. 5, 2001, pp. 1181-1218.

Wilson, Carter A. Racism: From Slavery to Advanced Capitalism. Sage Publications, 1996.

Lilijana Burcar

University of Ljubljana, Slovenia lilijana.burcar@guest.arnes.si

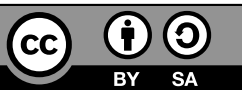

\section{Pomanjkljivosti in omejitve politike identitet in intersekcionalnosti v Hiši na ulici mangov Sandre Cisneros}

Članek temelji na sistemski kritiki politike identitet in intersekcionalnosti, ki danes podčrtujeta zahodno etablirano literarno teorijo in anglo-saksonsko literarno produkcijo. To kritiko uvaja skozi prizmo zapostavljenih in spregledanih kritičnih intervencij, ki so plod materialistične (literarne) sistemske teorije z zahodno marksističnimi feministkami na njenem čelu. Ta spoznanja članek aplicira na literarno analizo Hiše v ulici mangov Sandre Cisneros, izpostavljajoč pasti identitetnih politik in intersekcionalnosti, v katere je ujet roman, in iz česar izhaja, da se znotraj trikotnika rase, spola in razreda, zavedanje slednjega vse bolj briše do točke njegove odstranitve.

Ključne besede: razred, rasnost, spol, identitetne politike, intersekcionalnost, Hiša na ulici mangov, Sandra Cisneros

The author acknowledges the financial support from the Slovenian Research Agency (research core funding No. P6-0265). 